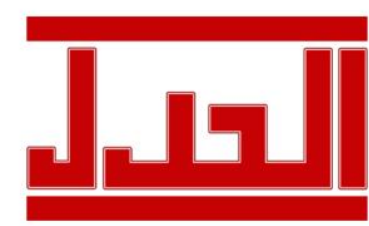

ISSN: $1979-4940$

E-ISSN: 2477-0124
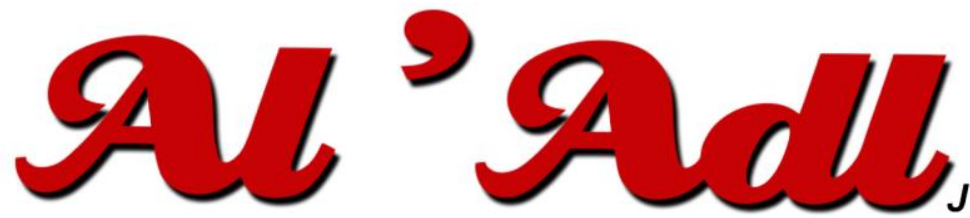

Jurnal Hukum

Editorial Office: Faculty of Law, Islamic University Of Kalimantan,

Jalan Adhyaksa No. 2 Kayutangi Banjarmasin, Kalimantan Selatan, Indonesia (70123)

Email: al_adl@uniska-bjm.ac.id

Web: http://ojs.uniska-bjm.ac.id

\title{
TUMPANG TINDIH REGULASI ADVOKAT DI INDONESIA
}

\section{Miftah Ulumudin Tsani \\ Universitas Islam Kalimantan MAB}

Jl. Adhyaksa No. 2 Kayutangi Kota Banjarmasin Kalimantan Selatan

Email: ulumudin.tsani@gmail.com

Submitted : 25 Januari 2021

Revised : 27 Januari 2021

Accepted : 30 Januari 2021

Published : 30 Januari 2021

\begin{abstract}
Advocates have an important role and function in a judicial system. Implementation of professional duties conducted by Advocates for upholding justice based on law and interests of the justice-seeking community including efforts to empower the community to provide awareness of their fundamental rights before the law. Provisions regarding Advocates are regulated in Law Number 18 of 2003 concerning Advocates, The Advocate Law is the main legal umbrella in Indonesia because there are no other laws and regulations that regulate Advocates. As time goes by, the Advocate Law is felt that it is no longer ideal and does not fit the needs of society, especially for Advocates, because there is an overlap regarding advocate regulations that are not aligned and consistent with the Advocate Law. The purpose of this paper is to find out several regulations issued by State Agencies cause regulations on Advocates to be blurred.
\end{abstract}

Keywords : Advocate; Overlapping; Regulation;.

Abstrak
Advokat mempunyai peranan dan fungsi penting dalam sebuah sistem peradilan. Pelaksanaan
tugas profesi dilakukan oleh Advokat demi tegaknya keadilan berdasarkan hukum dan untuk
kepentingan masyarakat pencari keadilan termasuk usaha memberdayakan masyarakat untuk
memberikan kesadaran mengenai hak-hak fundamental mereka di hadapan hukum. Ketentuan
mengenai Advokat diatur dalam Undang-Undang Nomor 18 Tahun 2003 Tentang Advokat,
Undan-Undang Advokat merupakan payung hukum utama di Indonesia karena memang tidak
ada Peraturan Perundang-Undangan lainnya yang mengatur mengenai Advokat. Seiring
berjalannya waktu Undan-Undang Advokat dirasa sudah tidak ideal dan tidak sesuai
kebutuhan masyarakat khususnya bagi Advokat, karena terjadi tumpang tindih mengenai
regulasi advokat yang tidak selaras dan konsisten dengan Undan-Undang Advokat. Tujuan


dari penulisan ini untuk mengetahui Beberapa aturan yang di terbitkan oleh Instansi Negara yang menyebabkan regulasi tentang Advokat menjadi kabur. Metode yang digunakan dalam penelitian ini adalah metode hukum normatif.

Kata Kunci : Advokat; Tumpang Tindih; Regulasi;

\section{PENDAHULUAN}

Konsep negara hukum terkait dengan istilah nomokrasi (nomocratie) atau kedaulatan hukum yang berarti bahwa penentu dalam penyelenggaraan kekuasaan negara adalah hukum. Konsep negara hukum yang paling dikenal di dunia adalah konsep negara hukum Rechtsstaat produk eropa Kontinental serta konsep negara hukum Rule of Law produk Anglo Saxon. ${ }^{1}$

Maksud dari negara hukum ialah suatu negara menyelenggarakan sistem pemerintahan dengan berdasarkan hukum sehingga penguasa tidak bisa menggunakan kekuasaannya semata-mata untuk menjalankan sistem pemerintahan. Indonesia merupakan salah satu negara hukum di dunia sebagaimana tersirat dalam Undang-Undang Dasar Negara Republik Indonesia Tahun 1945 Pasal Ayat (3). ${ }^{2}$ Adapun korelasi ketentuan lainnya pada UndangUndang Dasar Negara Republik Indonesia 1945 dimuat dalam ketentuan Pasal 27 Ayat (1) yang menyatakan bahwa segala warga Negara bersamaan kedudukannya di dalam hukum dan pemerintah wajib menjunjung hukum dan pemerintahan itu dengan tidak ada kecualinya serta ketentuan dalam Pasal 28 Ayat (5) yang berbunyi bahwa untuk penegakkan dan melindungi hak asasi manusia sesuai dengan prinsip negara hukum yang demokratis, maka pelaksanaan hak asasi manusia dijamin, diatur, dan dituangkan dalam peraturan perundang-undangan. Mengenai konsep negara hukum yang dianut Indonesia maka arah pelaksanaan sistem kenegaraan harus berdasarkan hukum, bukan kekuasaan.

Sebagai negara hukum maka salah satu indikator keberhasilan penyelenggaran suatu negara dapat dilihat dari aspek penegakkan hukum dalam negara itu sendiri. Menururt Lawrence M. Friedman seorang pakar sosiologi hukum menjelaskan bahwa ada empat elemen utama dari sistem hukum, yaitu substansi hukum, struktur hukum, budaya hukum dan dampak hukum. Dari ke-empat elemen tersebut nampak bahwa penegakkan hukum merupakan salah satu aspek penting yang termasuk dalam kelompok struktur hukum, karena penegakkan hukum merupakan indikator pencapain suatu kepastian hukum.

\footnotetext{
1 Jimly Ashiddiqie, 2006, Pengantar Ilmu Hukum Tata Negara, Jakarta : Mahkamah Konstitusi RI, hlm. 152.

${ }^{2}$ Bunyi Pasal 1 Ayat 3: Indonesia adalah Negara Hukum.
} 
Penegakan hukum adalah perhatian dan penggarapan perbuatan-perbuatan yang melawan hukum yang sungguh-sungguh terjadi (onrecht in actu) maupun perbuatan melawan hukum yang mungkin akan terjadi (onrecht in potentie). ${ }^{3}$ Satjipto rahardjo memberikan pengertian penegakkan hukum secara sederhana yaitu suatu usaha untuk mewujudkan ide-ide dan konsep-konsep menjadi kenyataan, maksudnya penegakan hukum adalah suatu proses

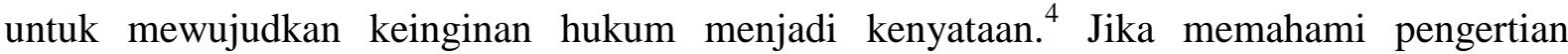
penegakkan hukum bisa ditarik pandangan bahwa penegakkan hukum juga ditujukan untuk menjamin kepastian hukum. Secara praktik proses penegakan hukum merupakan harmonisasi fungsi, tugas dan wewenang instansi atau lembaga yang bertugas menegakkan hukum ruang lingkup masing-masing dan berlandaskan sistem kerjasama demi mendukung tujuan yang akan dicapai.

Lawrence M. Friedman berpendapat bahwa, berhasil dan tidaknya penegakan hukum dipengaruhi oleh tiga unsur sistem hukum yaitu struktur hukum, substansi hukum, dan budaya hukum. Terkait struktur hukum, Reformasi internal lembaga penegak hukum harus dilakukan secara konsisten, profesional, dan berkelanjutan. Upaya pembenahan institusi hukum dari mafia peradilan mutlak dilaksanakan segera. Penegak hukum bersama-sama dengan hakim dan advokat harus dapat menjalankan tugasnya dengan sebaik-baiknya, sehingga mengakibatkan kepercayaan publik meningkat.

Terkait substansi hukum, Penyusunan serta pembentukan undang-undang dan perkembangan hukum kebiasaan harus serasi dan harmonis dengan kebutuhan masyarakat, harus objektif dan tidak mendiksriminiasi. Sedangkan Terkait budaya hukum, kesadaran publik terhadap hukum (termasuk sikap anti korupsi dan pelajaran budi pekerti dan moral) harus ditingkatkan, bahkan harus diajarkan sejak dini di dalam lingkup keluarga, termasuk bagaimana seorang warga negara memiliki hak dan kewajiban masing-masing yang harus dijalankan. 5

Apabila penegakkan dilaksanakan sesuai dengan 3 unsur sebagaimana disebutkan sebelumnya oleh Lawrence M. Friedman, maka pengakkan hukum akan ideal yang tentu saja sejalan dengan tujuan hukum. Namun permasalahan pengakkan hukum di Indonesia sampai saat ini masih sering terjadi, salah satu faktor yang menyebabkan munculnya persoalan mengenai peneggakan hukum di Indonesia adalah faktor advokat sebagai salah satu bagian

\footnotetext{
${ }^{3}$ Sudarto, Kapita Selekta Hukum Pidana, Alumni, Bandung, 1986, hlm. 111.

${ }_{5}^{4}$ Satjipto Rahardjo, Hukum dan Masyarakat, Angkasa, Bandung, 1980, hlm. 24.

5 https://www.hukumonline.com/berita/baca/lt5c2c4d8a2e4aa/refleksi-penegakan-hukum-indonesia2018-oleh--frans-h-winarta?page=all
} 
dari struktur hukum yang di rasa kurang memiliki integritas dan kemampuan yang mumpuni di bidang hukum khususnya dalam turut serta mengawal proses penegakkan hukum.

Advokat bersama hakim, jaksa serta polisi merupakan "Catur Wangsa Penegak Hukum" sebagaimana dimuat dalam ketentuan Pasal 5 Undang-Undang Nomor 18 Tahun 2003 tentang advokat ${ }^{6}$ yang mempunyai peranan dan fungsi yang signifikan dalam sebuah sistem peradilan. Pelaksanaan tugas profesi dilakukan oleh Advokat demi tegaknya keadilan berdasarkan hukum dan untuk kepentingan masyarakat pencari keadilan termasuk usaha memberdayakan masyarakat untuk memberikan kesadaran mengenai hak-hak fundamental mereka di hadapan hukum. Oleh karena itu, maka Advokat sebagai salah satu unsur sistem peradilan merupakan salah satu pilar dalam menegakkan supremasi hukum dan hak asasi manusia. $^{7}$

Namun pada kenyataannya tidak semua advokat menjalankan tugas profesinya sesuai dengan apa yang diamanatkan oleh undang-undang sehingga menyebabkan turunnya kepercayaan masyarakat terhadap kredibilitas dan integritas advokat di Indonesia. Salah satu faktor yang mempengaruhi ketidak jelasan peranan advokat di Indonesia adalah mengenai regulasi advokat itu sendiri. Kenyataannya regulasi advokat tidak hanya merujuk ketentuan sebagaimana tersirat pada Undang-Undang No. 18 Tahun 2003 Tentang Advokat, ada beberapa regulasi yang yang dikeluarkan oleh beberapa Instansi Negara dalam bidang hukum di Indonesia, diantaranya adalah Keputusan MK No. 35/PUU-XVI/2018 tanggal 28 November 2019 atas gugatan mengenai Status Organisasi Advokat di Indonesia, selanjutnya ada SK MA Nomor 73/KMA/HK.01/IX/2015 Tentang Penyumpahan Advokat dan Peraturan Kepala Polisi Negara Republik Indonesia ${ }^{8}$ Nomor 2 Tahun 2017 Tentang Tata Cara Pemberian Bantuan Hukum Oleh Kepolisian Negara Republik Indonesia. ${ }^{9}$

Jika melihat ke 3 (tiga) ketentuan yang diterbitkan oleh instansi terkait tersebut, ada beberapa hal yang tidak selaras dengan ketentuan-ketentuan lain yang khususnya ketentuan pada UU Advokat sehingga terkesan ada keadaan dimana terjadi tumpang tindih kebijakan mengenai regulasi Advokat di Indonesia, khususnya ketentuan mengenai Status Organisasi Advokat di Indonesia, Penyumpahan dan status Advokat sebagai Pegawai Negeri Sipil atau

\footnotetext{
${ }^{6}$ Selanjutnya disebut UU Advokat.

${ }^{7}$ Adnan Buyung Nasution, Arus Pemikiran Konstitusionalisme : Advokat, Kata Hasta Pustaka, Jakarta, 2007, hlm. 24.

${ }^{8}$ Selanjutnya disebut PERKAPOLRI

${ }^{9}$ Selanjutnya disebut Perkap No. 2 Tahun 2017.
} 
sekarang lebih dikenal dengan istilah Aparatur Sipil Negara (ASN) dan Pejabat Negara. ${ }^{10}$ Sehingga menyebabkan pengakkan hukum di Indonesia dirasa tidak ideal, serta pandangan masyarakat terhadap kredibilitas dan integritas Advokat di Indonesia menurun.

\section{RUMUSAN MASALAH}

Berdasarkan latar belakang masalah diatas, maka dapat dirumuskan suatu rumusan masalah yang akan diteliti yaitu bagaimana tumpang tindih beberapa aturan yang di terbitkan oleh Instansi negara yang menyebabkan regulasi tentang Advokat menjadi kabur?

\section{METODE PENELITIAN}

Dalam pembuatan sebuah karya ilmiah terutama karya ilmiah penelitian hukum diharuskan menggunakan metode penelitian hukum. Ilmu hukum berusaha untuk menampilkan hukum secara integral sesuai dengan kebutuhan kajian ilmu hukum itu sendiri, sehingga metode penelitian dibutuhkan untuk memperoleh arah penelitian yang komprehensif. ${ }^{11}$ Sebenarnya ilmu hukum mempunyai ciri-ciri sebagai ilmu yang bersifat preskriptif dan terapan. Dalam preskriptif, ilmu hukum mempelajari tujuan hukum, nilai-nilai keadilan dalam suatu hukum, baik buruk suatu aturan hukum, konsep-konsep dan norma hukum. sedangkan dalam ilmu terapan, ilmu hukum menetapkan suatu prosedur, ketentuanketentuan dan batasan-batasan dalam menegakan suatu aturan hukum. ${ }^{12}$ Metode penelitian yang di gunakan dalam artikel ini adalah metode penelitian yuridis normatif, dimana metode ini mengkaji permasalahan dari beberapa ketentuan perundang-undangan yang berlaku serta beberapa literature hokum serta pendapat-pendapat hokum dari para ahli hukum.

\section{PEMBAHASAN}

\section{A. Organisasi Advokat dalam Undang-Undang No. 18 Tahun 2003 Tentang Advokat dan Pasca Diterbitkannya Putusan Mahkamah Konstitusi No. 35/PUU-XVI/2018}

Salah satu konsideran menimbang dalam UU Advokat ini adalah meninjau dari konsep kekuasaan kehakiman yang harus bebas dari segala bentuk campu tangan dan

\footnotetext{
${ }^{10}$ Baca Pasal 3 Ayat (1) Huruf C UU Advokat.

11 Yati Nurhayati, "Perdebatan Metode Normatif dengan Metode Empirik Dalam Penelitian Ilmu Hukum Ditinjau Dari Karakter, Fungsi dan Tujuan Ilmu Hukum”, Jurnal Al Adl, Volume 5 Nomor 10, 2013, hlm. 15.

${ }^{12}$ Yati Nurhayati, Pengantar Ilmu Hukum, Nusa Media, Bandung, 2020, hlm. 9.
} 
pengaruh dari kepentingan-kepentingan diluar penegakkan hukum, sehingga memerlukan profesi advokat yang bebas, mandiri dan bertanggung jawab untuk dapat mencapai terselenggaranya suatu peradilan yang jujur, adil dan memiliki kepastian hukum bagi semua pihak para pencari keadilan dalam meneggakkan hukum, kebenaran, keadilan dan hak asasi manusia. Sehingga profesi Advokat perlu dijamin dan dilindungi oleh suatu Undang-Undang demi terselenggaranya upaya penegakkan supermasi hukum maka diterbitkanlah UndangUndang Nomor 18 Tahun 2003 Tentang Advokat yang berisi 13 Bab yang dimulai dengan ketentuan umum hingga ketentuan penutup.

Berdasarkan amanat UU Advokat dalam Pasal 32 ayat (4) yang berbunyi dalam waktu paling lambat 2 (dua) tahun setelah berlakunya undang-undang ini, Organisasi Advkoat telah terbentuk. Pada Ketentuan berikutnya yaitu Pasal 2 ayat (3) mengamanatkan kepada 8 (delapan) Organisasi Advokat yang ada yakni IKADIN, AAI, HAPI, SPI, AKHI, HKPM, dan APSI untuk sementara waktu menjalankan tugas dan wewenang Organisasi Advokat. Kemudian Pada tanggal 16 Juni 2003, kedelapan Organisasi Advokat ini kemudian sepakat untuk kembali memakai nama Komite Kerja Advokat Indonesia (KKAI). Maka pada tanggal 7 April 2005 Perhimpunan Advokat Indonesia ${ }^{13}$ yang di singkat Menjadi PERADI akhirnya resmi dibentuk dan diumumkan pada masyarakat. Dengan diresmikannya PERADI, maka PERADI memiliki kewenangan pembinaan dan pengawasan terhadap profesi Advokat. Wewenang tersebut diantaranya adalah sebagai berikut:

1. Melaksanakan Pendidikan Khusus Profesi Advokat atau PKPA;

2. Pengujian terhadap calon Advokat;

3. Pengangkatan Advokat;

4. Membuat Kode Etik Advokat;

5. Membentuk Dewan Kehormatan Advokat;

6. Membentuk Komisi Pengawas Advokat;

7. Melakukan pengawasan terhadap Advokat; dan

8. Memberhentikan Advokat.

Dari proses pendidikan, pengujian, pengangkatan pengawasan praktik sehari-hari, semuanya telah menjadi kewenangan PERADI berdasarkan ketentuan-ketentuan sebagaimana diatur dalam UU Advokat. Sedangkan satu-satunya yang tidak menjadi kewenangan advokat dalam regulasi tersebut adalah melakukan pengangkatan sumpah Advokat yang memang menjadi kewenangan Pengadilan Tinggi di bawah kordinasi Mahkamah Agung.

\footnotetext{
${ }^{13}$ Selanjutnya disebut PERADI
} 
Selanjutnya yang sering menjadi perdebatan diantara Advokat atupun penggiat hukum di Indonesia adalah mengenai sistem organisasi yang dianut, UU Advokat memang tidak secara jelas menyebutkan bahwa menganut sistem organisasi tunggal (single bar system) yang sepenuhnya di berikan kepada PERADI. Beberapa pihak menginginkan Advokat diwadahi lebih dari datu organisasi (multi bar system), dan para pihak tersebut mendirikan organisasi Advokat diluar kordinasi PERADI dan bertindak menjalankan wewenang organisasi namun tidak sepenuhnya menjalankan ketentuan-ketentuan sebagaimana tersirat dalam UU Advokat, Hal tersebut menyebabkan perselisihan kewenangan diantara organisasi Advokat. Yang paling nampak dari perselisahan tersebut yang sampai saat ini masih terjadi adalah mengenai usulan sumpah Advokat. Organisasi Advokat selain PERADI secara terus menerus mengajukan usulan pengambilan sumpah Advokat de Pengadilan Tinggi, hal tersebut dianggap oleh PERADI sebagai cacat hukum karena organisasi selain peradi tidak memiliki kewenangan untuk mengajukan usulan sumpah advokat.

Perselisihan mengenai status sistem organisasi single bar system atau multi bar system telah di putuskan oleh Mahkamah Konstitusi, yang terbaru telah diputuskan dalam Keputusan MK No. 35/PUU-XVI/2018 tanggal 28 November 2019. Namun dalam putusan tersebut pun tidak dengan tegas menunjuk bahwa PERADI sebagai satu-satunya organisasi Advokat karena ada poin pening dalam putusan tersebut yang menyatakan bahwa khusus kewenangan penyumpahan atau pengangkatan advokat, di masa mendatang organisasi-organisasi advokat selain PERADI, harus segera menyesuaikan dengan organisasi PERADI sebagai satu-satunya wadah profesi Advokat yang melekat delapan kewenangan termasuk kewenangan pengangkatan Advokat. Penegasan MK ini tidak terlepas dari keinginan kuat untuk membangun marwah Advokat sebagai profesi mulia (officium nobile) demi penguatan integritas, kompetensi, dan profesionalitas. ${ }^{14}$

Jika melihat poin dalam amar putusan tersebut bisa diartikan bahwa, Mahkamah Kontitusi tidak melarang pendirian organisasi Advokat diluar Peradi, Karena ada pertimbnagan bahwa pendirian organsasi dijamin oleh Undang-Undang Dasar NRI 1945 sebagaimana tertuang dalam ketentuan Pasal 28 dan Pasal 28E ayat (3) mengenai kebebasan berkumpul dan berserikat. Selanjutnya PERADI merasa bahwa putusan Mahkamah Konstitusi No. 35/PUU-XVI/2018 tidak menyebutkan bahwa organisasi Advokat selain PERADI tidak

14 https://www.hukumonline.com/berita/baca/lt5de22de5e34f2/putusan-wadah-organisasi-advokat-begini-pandangan-peradi-dan-kai diakses tanggal 15 Januari 2021 
memiliki 8 kewenangan organisasi Advokat sesuai UU Advokat sebagaimana tersirat juga dalam Putusan Mahkamah Konstitusi No. 66/PUU-VIII/2010 tanggal 27 Juni 2011.

Perselisihan mengenai organisasi advokat sudah sering diuji oleh Mahkamah Konstitusi terhitung sampai dengan 22 (dua puluh dua) kali, namun kenyataanya putusan tersebut tidak seluruhnya dipatuhi oleh semua pihak. Pada tanggal 25 September 2015, Mahkamah Agung melalui Surat Ketua MA No. 73/KMA/HK.01/IX/2015 justru memberikan kesempatan terhadap organisasi Advokat selain PERADI untuk dapat mengajukan usulan penyumpahan Calon Advokat di Pengadilan Tinggi pada wilayah hukum domisili Calon Advokat berada. Dalam tataran Konstitusi, persoalan perdebatan mengenai kewenangan organisasi sebenarnya sudah selesai. Namun dalam implementasi ternyata masih banyak persoalan yang timbul khususnya mengenai kedudukan PERADI sebagai satu-satunya organisasi Advokat yang berhak menjalankan 8 (delapan) kewenangan sesuai yang diberikan dalam UU Advokat masih dipertanyakan. Perdebatan tersebut muncul akibat diterbitkannya Surat Ketua Mahkamah Agung Perihal Penyumpahan Advokat yang dianggap tidak konsisten dan tidak selaras dengan Putusan Mahkamah Konstitusi.

\section{B. Kewenangan Pengusulan Sumpah Advokat Pasca Diterbitkannya Surat Keputusan Mahkamah Agung Nomor 73/KMA/HK.01/IX/2015 Perihal Penyumpahan Advokat}

Ketentuan mengenai kewajiban advokat untuk disumpah diatur dalam Pasal 4 Ayat (1) UU Advokat yang berbunyi :

"Sebelum menjalankan profesinya, Advokat wajib bersumpah menurut agamanya atau berjanji dengan sungguh-sungguh di sidang terbuka Pengadilan Tinggi di wilayah domisili hukumnya. Maka setiap advokat tidak dapat menjalankan tugas dan fungsi profesi Advokat apabila tidak menjalankan sumpah di Pengadilan Tinggi terlebih dahulu"

Dari Ketentuan Pasal 4 Ayat (1) juga dpat dipahami, bahwa memang kewenangan untuk melaksanakan penyumpahan tidak diberikan pada organisasi Advokat melainkan pada Pengadilan Tinggi sesuai dengan domisili hukum calon Advokat. Namun berikutnya memunculkan pertanyaan tentang siapa dan organisasi Advokat mana yang berhak atau memiliki kewenangan untuk mengusulkan penyumpahan terhadap Advokat.

Pertanyaan mengenai siapa yang berhak dan berwenang mengusulkan penyumpahan terhadap Advokat memang dirasa wajar, mengingat 8 (delapan) wewenang pembinaan serta pengawasan diserahkan kepada PERADI berdasarkan amanat UU Advokat dan Putusan Mahkamah Konstitusi No. No. 35/PUU-XVI/2018, namun memang tidak ada satupun 
ketentuan yang menyebutkan satu-satunya organisasi Advokat yang berhak dan memiliki kewenangan mengusulkan penyumpahan Advokat kepada Pengadilan Tinggi adalah PERADI.

Hal tersebut minimbulkan tafsir bahwa organisasi Advokat selain PERADI memiliki hak yang sama untuk mengusulkan penyumpahan terhadap anggotanya dengan alasan memang tidak ada ketentuan yang eksplisit menyebutkan bahwa kewenangan mengusulkan penyumpahan hanya diberikan kepada PERADI. Ditambah dengan diterbitkannya Surat Keputusan Mahkamah Agung No. 73/KMA/HK.01/IX/2015 mengamanatkan kepada Ketua Pengadilan Tinggi di seluruh Indonesia bahwa pengusulan sumpah dapat dilakukan baik oleh Peradi maupun Organisasi Advokat lainnya selain PERADI.

Ketua Mahkamah Agung menegaskan bahwa terhadap Advokat yang belum bersumpah atau berjanji, Ketua Pengadilan Tinggi berwenang melakukan penyumpahan terhadap Advokat yang memenuhi persyaratan dalam Pasal 2 dan Pasal 3 UU Advokat atas permohonan dari beberapa Organsasi Advokat yang mengatasnamakan PERADI dan Pengurus Organisasi Advokat lainnya hingga terbentuknya Undang-Undang Advokat yang baru. ${ }^{15}$ Maka dapat disimpulkan, seluruh organisasi Advokat memiliki hak untuk mengajukan usulan penyumpahan Advokat, tanpa memandang apakah organisasi Advokat tersebut telah memenuhi persyaratan dari aspek administrartif maupun kualikatif sebagaimana diatur dalam UU Advokat.

Surat Keputusan Mahkamah Agung No. 73/KMA/HK.01/IX/2015 Perihal Penyumpahan Advokat menimbulkan tafsir yang berbeda bagi pihak PERADI. Menurut para Advokat yang Tergabung dalam Organisasi Advokat PERADI memandang Surat Keputusan Mahkamah Agung tersebut tidak konsisten dan selaras dengan ketentuan dalam UU Advokat serta Putusan Mahkamah Konstitusi No. 35/PUU-XVI/2018. Penyumpahan Advokat berdasarkan Pasal 4 Ayat (1) itu dapat dilakukan telah melalui prsedur yaitu proses Pendidikan Khusus Profesi Advokat (PKPA), telah melaui lulus ujian Advokat dan telah diangkat sebagai Advokat oleh Organisasi Advokat yang menaunginya. Oleh sebab itu, prosedur penyumpahan Advokat adalah rangkain proses lanjutan dan menjadi satu-kesatuan yang tidak dapat dipisahkan dari proses-proses sebelumnya. Atas dasar tersebutlah, jika memahami Ketentuan Pasal tentang kewenangan mengadakan pendidikan, pengujian, dan pengangkatan Advokat itu, dan Pengusulan sumpah Advokat adalah awal menuju proses selanjutnya yakni penyumpahan di Pengadilan Tinggi. Maka melalui penafsiran tersebut PERADI mengklaim bahwa penafsiran sistematis tersebut dapatlah diketahui bahwa

\footnotetext{
${ }^{15}$ Baca Surat Keputusan Mahkamah Agung No. 73/KMA/HK.01/IX/2015 Angka 6.
} 
pengusulan sumpah Advokat adalah bagian satu-kesatuan yang tidak dapat dipisahkan dari 8 (delapan) wewenang Organisasi Advokat yang telah diamanatkan oleh UU Advokat yaitu PERADI. ${ }^{16}$ Oleh sebab itu pengajuan usulan sumpah Advokat merupakan bagian dari 8 (delapan) wewenang Organisasi Advokat yang telah diberikan kepada PERADI. Dengan demikin PERADI memiliki pandangan hukum tersendiri menanggapi tumpang tindih regulasi Advokat tersebut dan menyatakan bahwa satu-satunya Organisasi Advokat yang berhak untuk mengusulkan penyumpahan Advokat hanyalah Peradi dan Organiasasi Advokat selai Peradi tidak memiliki kewenangan untuk mengajukan usulan sumpah Advokat karena tidak memiliki hak untuk menjalankan 8 (delapan) wewenang pembinaan dan pengawasan Profesi Advokat.

Selanjutnya mencuat perselisihan mengenai keabsahan sumpah yang diajukan oleh PERADI dan Organisasi Advokat selain Peradi, mengingat Ketentuan Pasal 1 angka 5 Undang-Undang Nomor 30 Tahun 2014 tentang Administrasi Pemerintahan menegaskan Bahwa Wewenang adalah hak yang dimiliki oleh Badan dan/atau Pejabat Pemerintahan atau penyelenggara negara lainnya untuk mengambil keputusan dan/atau tindakan dalam penyelenggaraan pemerintahan. Hal tersebut juga ditegaskan oleh Mahkamah Konstitusi pada Putusan No. 014/PUU-IV/2006 yang menyatakan bahwa Organisasi PERADI sebagai satusatunya wadah profesi Advokat pada dasarnya adalah organ Negara dalam arti luas yang bersifat mandiri (Independent State Organ) yang melaksanakan fungsi Negara. Maka jika dilihat dari point penting dalam Surat Putusan Mahkamah Konstitusi No. 014/PUU-IV/2006, jelas menegaskan bahwa organisasi selain PERADI tidak memiliki kewenangan untuk melaksanakan fungsi Negara sebagaimana organ Negara.

Jika dilihat dari kedua pandangan yang berbeda mengenai penyumpahan Advokat berdasarkan uraian yang penulis paparkan sebelumnya tersebut mengakibatkan timbulnya multi tafsir terhadap siapakah atau pihak manakah yang memiliki kewenangan untuk mengajukan usulan sumpah Advokat karena masing-masing pihak memiliki pegangan peraturan yang memang dinilai tidak konsisten dan selaras dengan UU Advokat, sehingga mengakibatkan tidak tercapainya kepastian hukum dalam pengaturan regulasi Advokat di Indonesia.

16 http://www.peradi.or.id/index.php/infoterkini/detail/kedudukan-organisasi-advokat-selain-peradi,keabsahan-penyumpahan-advokat-yang-diusulkannya-dan-pertanggungjawaban-hukum-yang-dapat-dimintakanatasnya-analisa-yuridis-atas-impelementasi-putusan-mahkamah-konstitusi\# ftn1 diakses pada tanggal 25 Januari 2021. 


\section{PERKAPOLRI Nomor 2 Tahun 2017 Tentang Tata Cara Pemberian Bantuan Hukum Oleh Kepolisian Negara Republik Indonesia}

Berdasarkan PERKAPOLRI No. 2 Tahun 2017 tentang Tata Cara Pemberian Bantuan Hukum Oleh Kepolisian Negara Republik Indonesia, merupakan aturan yang berlaku secara internal dan seyogyanya hanya mengikat bagi Institusi Kepolisian Negara Republik Indonesia (POLRI) yang mengatur mengenai mekanisme bagi Anggota Polri yang Berhadapan dengan Hukum berhak mendapatkan bantuan hukum dari institusi POLRI, ketentuan tersebut tidak mengikat secara eksternal karena berdasarkan Pasal 7 ayat 1 Undang-Undang Republik Indonesia Nomor 12 Tahun 2011 tentang Pembentukan Peraturan Perundang-undangan telah memberikan Batasan yang dikualifikasikan sebagai peraturan perundang-undangan yang terdiri atas:

a. Undang-Undang Dasar Negara Republik Indonesia Tahun 1945;

b. Ketetapan Majelis Permusyawaratan Rakyat;

c. Undang-Undang/Peraturan Pemerintah Pengganti Undang-Undang;

d. Peraturan Pemerintah;

e. Peraturan Presiden;

f. Peraturan Daerah Provinsi; dan

g. Peraturan Daerah Kabupaten/Kota.

Maka mengacu terhadap ketentuan Undang-Undang Republik Indonesia Nomor 12 Tahun 2011 tentang Pembentukan Peraturan Perundang-undangan secara yuridis telah menentukan bahwa Peraturan Kepala Kepolisian Negara Republik Indonesia Nomor 2 Tahun 2017 tentang Tata Cara Pemberian Bantuan Hukum Oleh Kepolisian Negara Republik Indonesia bukanlah sebagai peraturan perundang-undangan yang memiliki konsekuensi yuridis yaitu mengikat secara umum.

Sehingga apabila ada peraturan yang dikeluarkan oleh institusi negara maka seharusnya selaras atau konsisten pada peraturan perundang-undangan sebagaimana disebutkan dalam Pasal 7 Ayat (1) UU No. 12 Tahun 2011 Tentang Pembentukan peraturan perundang-undangan. Namun pada PERKAPOLRI No. 2 Tahun 2017 justru dalam konsideran pertimbangannya tidak merujuk pada UU Advokat. Ini menjadi sebuah persoalan mengingat bantuan hukum yang dimuat dalam ketentuan PERKAPOLRI No. 2 Tahun 2017 Pasal 2 menyebutkan bahwa Pemberian Bantuan Hukum oleh Polri, meliputi:

a. Konsultasi Hukum;

b. Nasihat hukum;

c. Saran dan Pendapat ukum;

d. Advokasi; dan

e. Pendampingan. 
Disebutkan secara jelas dalam Pasal 2 huruf d PERAKPOLRI No. 2 Tahun 2017 pemberian bantuan hukum oleh Polri berupa Advokasi. Sehingga menjadi tidak relevan jika PERKAPOLRI No. 2 Tahun 2017 tidak merujuk pada Ketentuan UU Advokat sebagai Payung Hukum yang memang diakui secara Yuridis kekuatan hukumnya yang mengikat.

Selanjutnya kepada Pasal 1 angka 3 PERKAPOLRI No. 2 tahun 2017 menentukan bahwa Bantuan Hukum adalah segala usaha, upaya, kegiatan dalam rangka membantu menyelesaikan permasalahan hukum melalui peradilan maupun di luar peradilan. Sedangkan Pasal 1 angka 6 PERKAPOLRI No. 2 tahun 2017 menyatakan bahwa yang disebut Penasihat Hukum/Kuasa Hukum/Pendamping adalah Pegawai Negeri pada Polri yang mendapat perintah/tugas atau kuasa dari Pimpinan Polri untuk memberikan bantuan hukum.

Jika diamati maka muncul perselisihan peraturan, bagaimana bisa Penasihat Hukum atau Kuasa Hukum atau Pendamping merupakan Pegawai Negeri pada Institusi Polri, sedangkan pada UU Advokat Pasal 3 Ayat (1) huruf C secara Eksplisit menyatakan bahwa untuk dapat diangkat menjadi Advokat harus memenuhi persyaratan berupa tidak berstatus sebagai Pegawai Negeri atau Pejabat Negara. Hal tersebut memunculkan persepsi bahwa Pegawai Negeri pada Polri melakukan rangkap jabatan yang jelas hal tersebut dilarang dalam beberapa peraturan perundangan-undangan yang berkaitan dengan Pegawai Negeri sebagai berikut:

1. Pegawai Negeri dilarang menjadi Anggota dan/atau pengurus partai politik; ${ }^{17}$

2. PNS dilarang tanpa izin Pemerintah menjadi pegawai atau bekerja untuk negara lain dan/atau lembaga atau organisasi internasional; ${ }^{18}$

3. PNS dilarang bekerja pada perusahaan asing, konsultan asing, atau lembaga swadaya masyarakat asing. ${ }^{19}$

Ketentuan tersebut di atas dilanjutkan dengan Pasal 5 Ayat 1 PERKAPOLRI No. 2 Tahun 2017 menentukan bahwa Bantuan Hukum menjadi tanggung jawab Kepala Divisi Hukum Polri/Kepala Bidang Hukum Kepolisian Daerah dan ketentuan Pasal 5 ayat 2 menentukan bahwa Pelaksanaan Bantuan Hukum dilaksanakan oleh:

a. Anggota Polri dan/atau Pegawai Negeri Sipil Polri yang bertindak sebagai Penasihat Hukum/Kuasa Hukum/Pendamping berdasarkan surat perintah dari pimpinan Polri yang berwenang; dan

b. Bagian penerapan hukum dalam bentuk klarifikasi, kajian hukum, memberikan pendapat dan saran hukum secara yuridis terhadap tindak pidana umum, tindak pidana

${ }^{17}$ Baca Pasal 9 ayat (2) jo. Pasal 87 ayat (4) huruf C Undang-Undang Nomor 5 Tahun 2014 Tentang Aparatur Sipil Negara.

${ }^{18}$ Baca Pasal 4 angka 3 Peraturan Pemerintah Nomor 53 Tahun 2010 Tentang Disiplin Pegawai Negeri Sipil.

${ }^{19}$ Ibid. 
khusus, tindak pidana tertentu, hak asasi manusia, kode etik disiplin dan institusi yang memerlukan.

PERKAPOLRI Nomor 2 Tahun 2017 tentang Tata Cara Pemberian Bantuan Hukum Oleh Kepolisian Negara Republik Indonesia telah menimbulkan konflik norma didalam sistem hierarki peraturan perundang-undangan di Negara Indonesia, PERKAPOLRI No. 2 Tahun 2007 jelas memberikan konsekuensi hukum bagi oknum anggota kepolisian yang diduga telah melakukan tindak pidana di bela oleh Institusi Kepolisian yang bertindak seperti advokat dalam sistem peradilan pidana. Hal ini jelas bertentangan dengan UU Advokat sebagai landasan yuridis bagi advokat dalam menjalankan profesinya yang dsebut sebagai Profesi Terhormat (officium Nobile). Sedangkan Berdasarkan pasal 5 ayat (1) UU Advokat menyatakan bahwa Advokat berstatus sebagai penegak hukum, bebas dan mandiri yang dijamin oleh hukum dan peraturan perundang-undangan.

Negara memberikan kepastian hukum bagi advokat dalam menjalankan profesinya agar bebas dan mandiri tidak terpengaruh oleh kekuasaan lainnya terutama kekuasaan eksekutif (pemerintah) maka disahkan UU Advokat menentukan secara tegas bahwa profesi advokat telah dijamin keberadaanya oleh hukum dan statusnya sebagai penegak hukum. Lebih lanjut dalam penjelasan pasal 5 ayat (1) UU Advokat, dijelaskan bahwa yang dimaksud dengan advokat berstatus sebagai penegak hukum" adalah advokat sebagai salah satu perangkat dalam proses peradilan yang mempunyai kedudukan yang setara dengan penegak hukum lainnya dalam menegakkan hukum dan keadilan.

Secara Yuridis dan asas hukum tidak boleh peraturan yang berada dibawahnya bertentangan dengan peraturan yang berada diatasnya yang disebut sebagai asas Lex Superior Derogat Legi Inferior, sehingga telah jelas secara yuridis dan asas hukum ketentuam Peraturan Kepala Kepolisian Negara Republik Indonesia Nomor 2 Tahun 2017 tentang Tata Cara Pemberian Bantuan Hukum Oleh Kepolisian Negara Republik Indonesia telah tidak konsisten dan bahkan bertentangan dengan Undang-Undang Nomor 18 Tahun 2003 tentang Advokat.

\section{PENUTUP}

Regulasi advokat di Indonesia saat ini terjadi kerancuan, dimana kebijakan-kebijakan instansi negara terkait Advokat tidak selaras dan tidak konsisten antara satu kebijakan dengan kebijakan lainnya atau bahkan tidak sesuai dengan Undang-Undang yang berlaku yang dalam hal ini adalah UU Advokat. Dimana UU Advokat seharusnya menjadi payung hukum utama 
mengenai pengaturan Advokat di Indonesia secara yuridis. Hal tersebut berdampak pada kredibilitas dan integritas Advokat, faktor yang sangat mempengaruhi adalah diterbitkannya kebijakan-kebijakan hukum baik yang diterbitkan oleh Mahkamah Konstitusi maupun Mahkamah Agung mengenai calon Advokat yang akan bersumpah di Pengadilan Tinggi tidak mengatur mengenai kualifikasi sesuai dengan ketentuan dalam UU Advokat. Selain itu persoalan yang terjadi adalah mengenai status Pegawai Negeri atau Aparatur Sipil Negara yang merangkap jabatan menjadi Advokat, sebagaimana dalam PERKAPOLRI No. 2 Tahun 2017 tentang Tata Cara Pemberian Bantuan Hukum Oleh Kepolisian Negara Republik Indonesia tidak merujuk pada UU Advokat, padahal dalam PERKAPOLRI No. 2 Tahun 2017 Jelas menyatakan salah satu bentuk bantuan hukum yang diberikan berupa advokasi. Hal ini memunculkan keraguan terhadap peran profesi Advokat yang bebas dan mandiri tidak terpengaruh oleh kekuasaan lainnya terutama kekuasaan eksekutif (pemerintah). Tumpang tindih regulasi advokat tersebut berdampak pada masyarakat yang menilai bahwa peran Advokat dalam proses penegakan hukum tidak sesuai dengan kepentingan hukum. Alangkah baiknya semua pihak yang berkaitan dengan penegakan hukum di Indonesia sebaiknya berkeja sama untuk membuat suatu peraturan mengenai regulasi Advokat yang memiliki kepastian hukum dan memiliki kekuatan hukum yang mengikat.

\section{DAFTAR PUSTAKA}

\section{Buku}

Adnan Buyung Nasution, 2007, Arus Pemikiran Konstitusionalisme : Advokat, Kata Hasta Pustaka, Jakarta.

Jimly Ashiddiqie, 2006, Pengantar Ilmu Hukum Tata Negara, Mahkamah Konstitusi RI, Jakarta.

Satjipto rahardjo, 1980, Hukum dan Masyarakat, Angkasa, Bandung.

Sudarto, 1986, Kapita Selekta Hukum Pidana, Alumni, Bandung.

Yati Nurhayati, 2020. Pengantar Ilmu Hukum, Nusa Media, Bandung.

\section{Peraturan Perundang-Undangan}

Undang-Undang Dasar Negara Republik Indonesia Tahun 1945.

Undang-Undang Nomor 5 Tahun 2014 Tentang Aparatur Sipil Negara. 
Undang-Undang Nomor 18 Tahun 2003 Tentang Advokat.

Peraturan Kepala Kepolisi Negara Republik Indonesia Nomor 2 Tahun 2017 Tentang Tata Cara Pemberian Bantuan Hukum Oleh Kepolisian Negara Republik Indonesia.

Peraturan Pemerintah Nomor 53 Tahun 2010 Tentang Disiplin Pegawai Negeri Sipil.

Surat Keputusan Mahkamah Agung Nomor 73/KMA/HK.01/IX/2015 Perihal Penyumpahan Advokat.

Surat Keputusan Mahkamah Konstitusi Nomor 66/PUU-VIII/2010.

Surat Keputusan Mahkamah Konstitusi Nomor 35/PUU-XVI/2018.

\section{Jurnal}

Yati Nurhayati, "Perdebatan Metode Normatif dengan Metode Empirik Dalam Penelitian Ilmu Hukum Ditinjau Dari Karakter, Fungsi dan Tujuan Ilmu Hukum”, Jurnal Al Adl, Volume 5 Npmor 10, 2013.

\section{Internet}

https://www.hukumonline.com/berita/baca/lt5de22de5e34f2/putusan-wadah-organisasiadvokat--begini-pandangan-peradi-dan-kai

http://www.peradi.or.id/index.php/infoterkini/detail/kedudukan-organisasi-advokat-selainperadi,-keabsahan-penyumpahan-advokat-yang-diusulkannya-danpertanggungjawaban-hukum-yang-dapat-dimintakan-atasnya-analisa-yuridis-atasimpelementasi-putusan-mahkamah-konstitusi\#_ftn1

https://www.hukumonline.com/berita/baca/lt5c2c4d8a2e4aa/refleksi-penegakan-hukumindonesia-2018-oleh--frans-h-winarta?page=all 